\section{SEXUAL VIOLATION AND TRAUMA IN HISTORICAL PERSPECTIVE}

\author{
Joanna Bourke \\ School of History, Classics, and Archaeology \\ Birkbeck College \\ Malet Street \\ London WC1E $7 H X$
}

$U K$

RESUMEN: El trauma no constituye una forma universal de expresión de los efectos de un "suceso desagradable" sino que es construido socialmente. En el caso de la violación, el trauma psicológico es una forma relativamente reciente de conceptualizar las consecuencias de la agresión. En este artículo se examina el desarrollo de la noción de trauma en manuales psiquiátricos, legales y forenses, a propósito de las víctimas de violación, y se investigan las razones para su relativamente reciente puesta en práctica.

PALABRAS CLAVE: Trauma; violación; violencia sexual.

Trauma narratives are the defining feature of late modernity. Confessional renderings of stories of violation are so ubiquitous that they seem to be a universal constant, regardless of historical time or geographical place. Sexual assault has become the pre-eminent example of an experience that is framed in terms of trauma. In public discourse, rape "survivors" hold a special place in defining an extreme point of psychological distress. Historically, however, this has not always been the case. Indeed, psychological trauma arising from sexual assault is a relatively new way to frame the aftermath of attack. As I will argue in this article, "bad events" other than rape were more liable to be narrated in terms of psychological trauma. Why was rape-trauma introduced relatively late into discussions of trauma in Britain and the USA, and what was the impact of the invention of the diagnosis "rape trauma syndrome"?

\section{NarRatives OF VictimhoOd}

It is commonplace to observe how little attention was paid to victims of sexual assault until the feminist in-

\section{VIOLACIÓN Y TRAUMA DESDE UNA PERSPECTIVA HISTÓRICA}

ABSTRACT: Trauma is not a universal way of speaking about the effects of "bad events" but is socially constructed. In the case of rape, psychological trauma is a relatively recent way of conceptualising the aftermath of violence. This article examines the development within psychiatric, legal, and forensic textbooks of the notion of "trauma" in reference to rape victims, and investigates the reasons for its relatively recent application.

KEY WORDS: Trauma; rape; sexual violence.

terventions of the 1970s onwards. Until that period, it is difficult to find extensive debate about the needs of rape victims. Medical services ignored them. According to Index Medicine between 1957 and 1966, no public health journal contained articles on rape. As late as 1957, a 548-page study on Sexual Offences by the Cambridge Department on Criminal Science devoted only a couple of sentences to the emotional responses of rape victims (104). Even these sentences were embedded in a section entitled "Physical Consequences to the Victim", in which the attention focussed primarily on bodily injuries, venereal diseases, and pregnancy. As we shall see shortly, a dearth of analysis of the psychological aftermath of sexual assault can be observed in all the major psychological and psychiatric journals prior to the 1970s.

It took until 1970 for the first substantial study of rape trauma to be published. In that year, Sandra Sutherland and Donald J. Scherl published "Patterns of Response Among Victims of Rape" in the American Journal of Orthopsychiatry. They were the first to delineate the "normal" and predictable psychological after-effects of rape. Four years later, the American Journal of Psychiatry published Ann 
Wolbert Burgess' and Lynda Lytle Holmstrom's detailed analysis of 92 rape victims admitted to the emergency room of Boston City Hospital. Burgess and Holmstrom effectively invented a new diagnosis called "rape trauma syndrome". They defined this syndrome as an "acute stress reaction to a life-threatening situation". Crucially, they regarded the women sufferers as "normal", and thus not necessarily requiring any help with "previous problems".

Indeed, from the 1970s, sexual assault was widely agreed to be exceptionally traumatic. In 1976 when a large sample of physicians were asked whether they believed that the trauma of sexual assault was worse than that of physical assault, 68 per cent agreed compared with only seven per cent who believed it to be less traumatic. Nevertheless, physicians lagged significantly behind the views of psychology students, polled in the same survey. 81 per cent of male students and 90 per cent of female students believed that sexual assault was more traumatic than physical assault. Interestingly, the authors of the report believed that the "correct" response to the question comparing the severity of emotional trauma for sexual versus physical assault was "This is unknown" (McGuire and Stern, 1976, 103-7).

Finally, in the 1970s and 1980s, one influential feminist strand of debate about rape also moved decisively towards the "inner trauma" model. Some feminist therapists went so far as to argue that all women were suffering from posttraumatic stress disorder or "insidious trauma". As Laura Brown argued in her chapter in Cathy Caruth's influential Trauma: Explorations in Memory (1995), "No one has yet beaten or raped me.... That is not to say that no one ever will". Every woman was a PTSD sufferer brought on by the stress of knowing that "they may be raped at any time and by anyone" (107). The fact that rape victims experienced very long term consequences, which could last their entire life, had become mainstream.

\section{Psychological States and Sexual Assault Prior TO THE 1970s}

This was very different to the way sexual assault was discussed prior to the 1970s. What is immediately striking in the earlier literature is the absence of any discussion of psychological states arising from assault. Mental states typically appeared in only one context: that of false accusations of rape. Thus, it was usual for forensic and psychiatric textbooks to discuss hysteria as a condition that resulted in false accusations of rape, rather than being caused by rape.

This refusal to identify sexual assault as a casual element in inciting mental disturbances was particularly notable since heightened emotional states - particularly fear states - were acknowledged to be pathogenic. Angelo Mosso's influential La Paura (1884) had been translated into English in 1896, effectively propagating the devastating physical effects of fear on the human organism. Not surprisingly, fear was blamed most frequently for the genesis of hysteria. In the words of neurologist Charles Loomis Dana in his Text-Book of Nervous Diseases and Psychiatry (1898) "the most important single exciting factor [in hysteria] is powerful emotion, particularly fear" (239). In 1909, a powerfully argued article by the Professor of Neurology at the University of Philadelphia categorically stated that emotional shock, particularly fear, was the "chief exciting cause" of hysteria because it affected the central nervous system and "especially portions of the brain". "Physical perturbation", he concluded, "occurs before or coincident with the psychic disorder, fright, or whatever else, alleged to be the chief agency in causation" (Mills, 1909, 231-51). In 1947, an article on "The Importance of the Emotional Factor in the Convulsive Disorders of Children" placed immense emphasis on fear in causing epilepsy, but the vaguely termed "early traumatic experiences" included things such as "disturbing dreams, dread of failure in school, feelings about home", but nothing suggesting sexual assault (Jensen, 1947, 130).

\section{The "Trauma" of Rape}

In nineteenth century rape accounts, the term trauma retained its original Greek meaning $-\tau \rho \alpha \nu \mu \alpha$ as a bodily injury. When the effects of rape were discussed, attention was paid exclusively to physical and moral realms. Thus, in Alfred Swaine Taylor's Medical Jurisprudence (1861), physicians were reminded that it was possible for a young girl to "sustain all the injury, morally and physically, which the perpetration of the crime can possibly bring down 
upon her". However, Taylor went on to describe the injury of rape solely in terms of damage to tissues, venereal encrustations, and death (687-98). Even Charles Gilbert Chaddock's highly influential chapter "Sexual Crimes" in A System of Legal Medicine (1900) only described the physical consequences of rape. The paragraph entitled "Secondary Consequences" admitted that "medico-legal questions may arise concerning the ultimate consequences of rape to the victim", but psychological consequences were markedly absent. In his words,

"Impregnation may result, and place additional liability on the ravisher. Injuries inflicted affect the health of the female; and such injuries may even cause death... Such cases show that death, under such circumstances, may result early or late, in accordance with the immediate cause. Thus it may be due to shock, hemorrhage [sic], sepsis, and to hemorrhages [sic] into the central nervous system. Genital wounds may directly or indirectly implicate the peritoneal cavity and lead to a fatal peritonitis" (544).

When a woman's emotional response to rape was discussed, it was generally to insist that the victim had been rendered "insensible". Both in forensic descriptions and in more popular accounts of rape in the nineteenth century, the woman claimed to have become "insensible" at some point during the attack. Thus, a rape victim in The Times on 8 March 1866 was described as "very ill, after lying in a fainting state some time" (1866). She was "in a state of fever" (The Times, 21 September 1822). She was in a "state of prostration" (The Times, 7 September 1877). Forensic texts such as Horatio Storer's "The Law of Rape" (1868), presumed that victims would be rendered "insensible by fright" (59). As Francis Ogston predicted in Lectures in Medical Jurisprudence (1878), female victims were prone to be rendered "insensible". Unusually, he did accord a role to hysteria arising "from terror or shame", but it was a "profound hysteric [sic] coma" which only lasted "some hours" (119). The state of "syncope" arising from terror accompanied rape rather than constituting a longer-term effect of the attack.

The typical rape account in public debates in the nineteenth century placed great emphasis on a woman's "stout resistance" (as Ogston expressed it), followed by "insensibility", which allowed the rape to take place. In part, this emphasis on "stout resistance" was dictated by a legal culture, with its profoundly female-hostile insistence on "against her will" or that never-defined notion of "without her consent". However, legal culture alone does not explain the almost obsessive recitation of the mantra of being rendered "insensible". There were two other reasons, one relating to ideas about the effect of fear and the other to questions of resistance. From the nineteenth century, psychiatric investigations into the effects of fear favoured the notion that fear was a "depressing passion", as Onesipherous W. Bartley insisted in his influential $A$ Treatise on Forensic Medicine or Medical Jurisprudence (1815). The tendency of fear to render people insentient explained why raped women could never become pregnant. In Bartley's words,

"when a person or persons are in coitu, under the depressing passions, as terror, apprehension, excessive grief, fear, alarm, and the like, conception cannot be the result; for these passions suspend (or if I may be allowed the expression) paralyze every energy, mental or corporeal".

If a woman who claimed to have been raped did become pregnant, this was evidence that she was lying: pregnancy required the "cheering influence" of an "exciting passion, such as hope" (43).

Bartley's belief in the impossibility of pregnancy without sexual excitation had a long life but was in rapid decline by the mid-nineteenth century. Nevertheless, the link between fear and "freezing" remained strong. In the words of an anonymous author writing in the American Journal of Insanity in April 1848, in fear states, the

"action of the heart is diminished, paleness ensues, the pulse becomes small, weak or irregular, and the secretions are suppressed or deranged. When the fear is extreme, or of long continuance, then more dangerous effects arise, such as convulsions, epilepsy, insanity or death".

Often, the author continued, the "immediate effect of the sudden shock upon the nervous system" was to "diminish the action of the heart", a consequence of which was insensibility or death (280 and 284). Bodily organs collapsed under the impulse of terror.

However, it is also plausible to suggest that this emphasis on the victim's insensibility was due to the commonly accepted belief that it was actually impossible to rape

ARBOR CLXXXVI 743 mayo-junio [2010] 407-416 ISSN: 0210-1963 
a resisting woman. In a phrase used time and again in nineteenth-century textbooks of medical jurisprudence, it was "impossible to sheath a sword into a vibrating scabbard". Metaphorically, the penis was coded as a weapon; the vagina, its passive receptacle. Merely by "vibrating", this receptacle could ward off attack. Almost without exception, jurists and physicians assumed not only that women would resist any attack on their honour, but (much more importantly) that they were physically strong and thus sure to succeed. As John Ayrton Paris and J. S. M. Fonblanque expressed it in Medical Jurisprudence (1823), "It is at all times difficult to believe that in a mere conflict of strength, any woman of moderate power of body and mind could suffer violation, so long at least as she retained her self possession" (423). The last phrase was important: "so long at least as she retained her self possession" or did not become "insensible".

Although this belief that a resisting woman could not be raped continued well into the late-twentieth century (albeit for psychological as opposed to corporeal reasons, as we shall see later), in the nineteenth century, the belief was instrumental in requiring rape victims to claim to have lost their mental faculties. Insensibility was important for victims and their defenders because it provided a convincing physical reason why some women failed to successfully fight off their attackers.

From the end of the nineteenth century, however, it is possible to detect a change in this notion that (unless rendered insensible) all women would fight back and have a very good chance of success. Increasingly, a clear distinction started to be made between labouring or working women and their more delicate cousins. The introduction of a class-bias can be illustrated by looking at Alfred Swaine Taylor's Medical Jurisprudence (1861) in which he began by reciting the common mantra that rape could only take place if a woman fell into "a state of syncope". However, he went on to warn physicians and judges against showing

\footnotetext{
"too great distrust... in reference to the amount of resistance offered by women of undoubted character. Inability to resist from terror, as well as horror at her situation, may lead a woman to succumb to the force of a ravisher, without offering that degree of resistance which is generally expected from a woman so situated" (713).
}

Taylor was one of the earliest commentators to make this distinction. It became a common mantra in forensic and legal textbooks from the late nineteenth century. In the words of J. Dixon Mann in an influential book of the 1890s, "women of the lower classes" were "accustomed to rough play" and thus had "acquire[d] the habit of defending themselves against sportive violence". Their "capacity for defence" rendered them capable of frustrating the attempts of any "ravisher". In case the point was not clear enough, Mann candidly contrasted the sturdy working woman with her more "delicately nurtured" counterpart who might be "so appalled by the unwonted [sic] violence that her faculties may be partially benumbed and her powers of resistance correspondingly enfeebled" (102). Women of the lower classes were "more used to roughness", echoed the author of Forensic Medicine. A Text-Book for Students and Practitioners (1925), and were thus less liable to be terrified than "a more refined type of woman would be" (221). Even the type of violence alleged to be directed at working-class women was disparaged - it was "sportive violence", according to Mann, and thus should be gamely repelled. The working-class woman could fight off any assailant. The unrapeable woman hailed from humble homes. In contrast, the burgher's daughter or wife was presumed to be physically weaker than men (and their "ravishers" were presumed to hail from the brawny classes), and, more important, she possessed emotional depth that rendered her incapable of effectively repelling attack. Middle-class women were possessed of an "inner self" (and not simply a body) that could be violated.

\section{The Invention of Psychological Trauma}

Why should this paucity of discussion in British and American forensic and psychiatric texts of long-term psychological distress as the aftermath of rape be surprising? In part, it is because the psychological aspects of rape had been examined elsewhere in Europe. In Étude medico-légale sur les attentats aux mœurs (1878), eminent French forensic physician Ambroise Tardieu documented hundreds of cases of sexual abuse (mainly of children), carefully delineating the serious psychological consequences of assault. Drawing on the work of French neurologist Jean-Martin Charcot, Freud's early work insisted that the "ultimate cause of hysteria always is the sexual seduction of a child by an 
adult". The work of pioneering French psychologist Pierre Janet and Hungarian psychoanalyst Sándor Ferenczi also provided innumerable examples of the psychic effects of sexual assault. Janet's patients included women who suffered rape or incest and responded to it by dissociation. According to Janet, frightening experiences could not be successfully integrated into the memory, so they were split off from consciousness. It wasn't until the 1980s that his views were taken up by Anglo-American psychiatrists examining extremes of dissociation in split personalities.

The highly influential and widely discussed work of such theorists in identifying an "inner" psychological space which was either traumatised by unconscious forces (the mimetic approach) or responded passively to external impressions in ways that were traumatic (the anti-mimetic approach) have led many cultural theorists to assume that psychological ideas were seminal in the construction of the modern subject. However, as we have already seen, it took until the late twentieth century for "trauma" to slip under the skin into a psychological space in forensic narratives of sexual violation of girls and women.

This is remarkably late for another reason too: that is, psychological trauma was very much present from 1866 in British and American forensic and legal texts relating to other forms of violence. Psychological trauma appeared most vividly in contexts related to industrialisation, especially railway accidents (from 1866,) and war (from 1915).

In 1866, John Eric Erichsen, professor of surgery at University College Hospital in London, coined the term "railway spine", drawing a link between physical states and nervous disarrangement. "In no ordinary accident", Erichsen concluded in On Railway and Other Injuries of the Nervous System (1866),

can the shock be so great as in those that occur on railways. The rapidity of the movement, the momentum of the person injured, the suddenness of its arrest, the helplessness of the sufferers, and the natural perturbation of mind that must disturb the bravest, are all circumstances that of a necessity greatly increases the severity of the resulting injury to the nervous system, and that justly cause these cases to be considered as somewhat exceptional from ordinary accidents (9).
His central idea was that the physical injury to the spinal cord caused the nervous symptoms. When Erichsen revised his book in 1875, under the title On Concussion of the Spine, Nervous Shock, and Other Obscure Injuries of the Nervous System in Their Clinical and Medico-Legal Aspects, he was much more willing to give psychological shock an independent role to organic lesions in causing nervous disorders. In his words,

"The mental or moral unconsciousness may occur without the infliction of any physical injury, blow, or direct violence to the head or spine. It is commonly met with in persons who have been exposed to comparatively trifling degrees of violence, who have suffered nothing more than a general shock or concussion of the system".

Psychological trauma was "probably dependent in a great measure upon the influence of fear", he concluded (195).

Trauma was also widely seen to have arisen out of the terror of combat. The First World War saw thousands of soldiers being diagnosed with "shell shock", "hysteria", "conversion neuroses" and suchlike, drawing a strong connection between extremes of fear and nervous collapse. I have written about this elsewhere (Bourke, 1996).

These discussions of the relationship between extreme fear arising from severe external threat might seem, on the surface, to be easily applicable to sexual trauma. However, there were many reasons why the link between trauma and industrialisation were not easily applied to women - that is, until the invention of Post-Traumatic Stress Disorder (PTSD) in 1980. These early trauma studies were being carried out at a time where the areas undergoing most rapid social change were public spheres, dominated by men. Notions of trauma thus arose naturally out of white male experiences. As a consequence, when rape victims did not act in ways predicted by this industrial/war trauma model, their feelings were easily discounted. Railway accidents and war were seen as wholly "unnatural" events, a brutal abreaction of civilisation, an unequal clash of man and machine. Furthermore, the unequal clash between the corporeal body and industrialisation was assumed to be a great and terrifying one. The physical harm done to women in sexual assault was rarely regarded as approximating that experienced in railway carriages. In contrast, rape was situated within "normal" sexual practices. 
While women did not need the diagnosis of psychological trauma because the social trauma of attack could be recognised, men required an additional explanation for why they "broke up".

Furthermore, in the case of both railway accidents and war, the issue at stage was fiscal - compensation and pensions. Railway passengers and soldiers were conceived of as passive victims of calamity: in contrast, it was often asked, might rape victims be complicit in their misfortune? Even in cases where sexual violence was visceral, the wounds raw and plain for all to see, there was still no need to appeal to notions of psychological trauma because the perpetrator could be individualised and the "solution" sought within penal law.

Even Freud's early seduction theory which illuminated discussions about the relationship between childhood sexual trauma and later psychological effects provided little space for women's experience of rape in adulthood. According to one reading of Freud, it was not the traumatic event itself that led to trauma but two non-traumatic events: the first being the initial sexual assault (not experienced as traumatic because the child could not grasp its meaning) and the second being the memory of that event which had been sparked by another non-traumatic event. This dynamic could not easily be employed to account for the responses of women raped as sentient adults.

There were other reasons, however, why psychological trauma was not seen as an inevitable consequence of rape. Nineteenth-century alienists placed great emphasis on hereditary as leading to insanity. This idea was especially strong when it came to understanding the aetiology of female hysterics. As a consequence, it was difficult to allow that rape in itself could lead to mental or emotional problems. The notion that rape might have been a precipitating factor, bringing to the surface "hereditary predispositions", simply served to stigmatise the victim further.

\section{Sexual Violence and "Frigidity"}

There is one major exception to the argument that psychiatric texts prior to the 1970s ignored the psychological effects of rape. From the 1920s, early sexologists identified "frigidity" as arising from early experiences of sexual abuse. Particularly striking is the word of Gladys C. Terry, who investigated the lives of 100 married women in the 1920s. Terry started with the supposition that there was a "relationship between certain types of early events and conditions and certain types of adult behavior". She observed that amongst her sample of 100 women there was a subgroup who either had "an inadequate capacity for response to the sex act with their husbands, i.e., they do not have the fully releasing climax (orgasm) with which the sex act normally terminates for women" or they were "seriously dissatisfied with their marriages". Could there be some experiences shared by these women that their more contentedly-married sisters did not share? After a laborious description of social-science methodology prior to computerised systems, Terry was able to identify two distinctive groups within her sample. Group A were women who had been "victims of an incestuous aggression" during their youth while Group X had never experienced "early sexual aggression". She found that 88 per cent of women in Group A had serious difficulties in "marital sex relationship by reason of their strongly negatively conditioned reactions to it". Indeed, none of the women in Group A had experienced orgasm. All of these women "evinced symptoms which are classified... as neurotic - they are badly adjusted and highly unstable women". In contrast, nearly 88 per cent of women in Group X experienced orgasm in the sex act most of the time. Women who had been exposed to "terrifying sex aggression" in childhood, Terry concluded, had been "conditioned" to "react with feelings of fear and shame to all sex curiosities and impulsions" and were thus prone to "develop a psychoneurosis" (Terry, 1929, 881-99).

This idea that the experience of violence in sexual relations would have a disastrous effect on a woman's ability to gain sexual pleasure later in her life was a common motif in early twentieth century sexology. It is important to point out, however, that the "problem" of women's frigidity was not generally linked to her pleasure or health but to that of her husband. Thus, the authors of "Group Therapy in Sexual Maladjustment" (1950-51) confidently stated that childhood experiences of sexual aggression "do not always have a traumatic effect", except for the way they "influence[d] sexual reactions". That "something that happened to me when I was a child", on which one of their patients coyly 
blamed her subsequent frigidity, meant that she had to be treated for "sexual maladjustment" (199). In other words, the effect of sexual assault was dysfunction within marriage: the failure to "please" a husband.

Even more striking, the violence was frequently regarded as emanating from husbands in the first place. Forcible sex imposed on newly-wed women by their husbands was regarded as particularly dangerous and liable to lead to "frigidity". As Walter P. Gallichan lamented in Sexual Apathy and Coldness in Women (1928), "without any mental preparation for the physical consummation of marriage, a young bride is exposed dangerously to the risk of nervous disturbance, psychic sexual frigidity, an emotional recoil from her partner, and physical injury" (97). According to the author of Christianity and Sex Problems (1906), forced intercourse might make the wife repulsed by sex - and revulsion could easily develop into "chronic frigidity" (129).

In this conceptualisation of women's breakdown in the context of rape, the psychological harm of marital rape was assumed to be borne by the husband. Forcing a wife to have sex harmed the "nerves" of the husband. Aggressive husbands were in danger of suffering from a "general weakness of the nervous system", a "weakening of the joints", a "softening of the muscles" and a "want of strength, according to John Cowan in The Science of a New Life" $(1869,105)$. Nearly two decades later, a similar catalogue of woes was reeled off by the widely read author of The Transmission of Life (1884). Forcing sex on an unwilling wife risked giving the husband heart palpitations, impairing his digestion, and causing dyspepsia. The sexually abusive husband would literally observe his strength seeping away. Even worse, he would suffer spermatorrhoea (that is, the involuntary drooling of semen without erection) and his "genetic powers" would "lose their vigor" (179-80). The offspring of forced sex within marriage would also inherit their father's weakness, having been endowed even before birth with "lustful passions and morbid appetites" (Stockham, 1889, 154). Indeed, the effects (on the husband) of forcing sex on a wife were similar to those of self-abuse or masturbation. According to this perspective, male bodies were a closed system, sapped by ordinary sexual intercourse but doubly drained if the husband had to use force to attain what he hankered after.

\section{The Effect of PTSD}

As argued thus far, in texts prior to the 1970s sexual abuse was not regarded as having much causal significance in the development of emotional disorders, except for increasing the woman's risk of frigidity. In Britain and America, psychological trauma entered public discourse in relation to the crisis of industrialisation and war. In contrast, during the debates from the 1970s, the language of wartime trauma became linked with that of rape. When Abram Kardiner first invented the term "post-traumatic stress disorder" in 1941, he did not intend it to apply outside of war neuroses. Yet, by the 1970s, a member of the Health Services Administration in Washington DC was able to compare rape victims to "soldiers after combat", believing that both needed to "abreact the dramatic event.... with someone who can listen sympathetically" (Zuspan, 1974, 143). As a physician and St Mary's Hospital in Manchester put it in 1991, in rape victims "there is often a change of personality similar to that described in First World War soldiers after their experiences in the trenches, and more recently in Vietnam veterans" (Duddle, 1991, 27).

This expansion in the application of PTSD to non-war traumas was not inevitable. Not all moral harms were fashioned into medico-legal one: fears inspired by combat, for instance, were admitted but not the terror arising from unemployment or severe poverty. What was the advantage in looking at rape trauma through the lens of PTSD?

Unlike other diagnoses, PTSD had a number of features that made it conducive to being applied to rape survivors. It placed significance on an "outside" "bad event" that had an "inside" effect. It was largely applied to experiences occurring in adulthood, rather than infancy. Compared with other mental illnesses, the disorder was burdened with fewer stigmas - it enabled the sufferer to remain "good"/ innocent. In part, it allowed it to be biologised and thus removed the moral stigma attached.

Furthermore, for psychiatrists of a range of perspectives, PTSD allowed for a bewilderingly large range of symptoms - any number of which might only appear after a long time-lag (unlike railway spine or shell shock). Most important, although the disorder was "predicated on a movement from the traumatic event to the symptoms... in practice it leaves open the possibility of moving in the

ARBOR CLXXXVI 743 mayo-junio [2010] 407-416 ISSN: 0210-1963

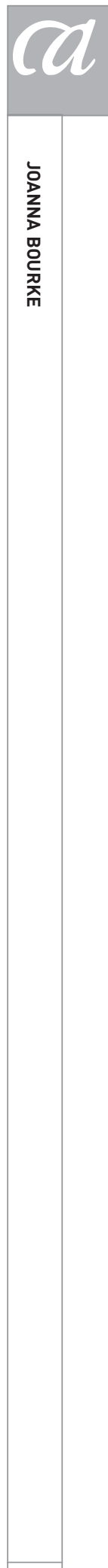


other direction, from the symptoms to the trauma" - or the "embodied memory". Feminist analysts found this helpful when faced with distressed women, the source of whose pain was obscure. It allowed therapists and patients to bypass questions of victim complicity. Finally, it embraced any number of explanatory theories. PTSD was a label given to symptoms; it remained neutral as to explanation. In terms of institutional power, this was auspicious, allowing the full range and diversity of the therapy industry to invest in its propagation.

The increasing psychological focus with regards sexually assaulted women had three significant effects. First, rape could involve unconscious complicity on the part of the victim. As David Abrahamsen, criminologist and former director of scientific research at Sing Sing prison in New York, put it in his influential The Psychology of Crime (1960):

\begin{abstract}
"the victim herself unconsciously also may tempt the offender. The conscious or unconscious biological and psychological attraction between man and woman does not exist only on the part of the offender toward the woman but also on her part toward him, which...[is] the impetus for his sexual attack..... We sometimes find this seductive inclination even in young girls" (160).
\end{abstract}

This appeal to shared biological and psychological drives was used to explain why rape victims often felt guilty for what had happened: they were guilty. From this perspective, free will was an unstable concept upon which to base agency because unconscious forces could cause the faculties of reason to dissipate with startling rapidity. According to this view, to be human was to be possessed of an inner psychological self that was profoundly suggestible.

As a consequence, the act of diagnosing psychological trauma was readily used by psychiatrists against the victims. In the words of the authors of "The Medical Examination of Alleged Rape", published in The Western Journal of Medicine in 1974,

"For the innocent victim, [rape] is a very traumatic and emotional ordeal. If the woman appears to be distraught, emotionally upset or frightened, this would tend to support her story. Conversely, a casual or almost nonchalant attitude after an alleged vicious and forcible attack might cause some doubt about the truth of the history" (331).

Thus, psychiatrists were invited to examine the complainant to discover if her emotional behaviour indicated that she was a "true" rape victim. Some psychiatrists were particularly pro-active in deciding whether the complainant had a "psychiatric condition that may have caused her to fantasize the sexual assault, even if she truly believed that it happened" (Melanson, 1994, 960-62). In terms of current debates about the subsuming rape law under assault legislation (generally including a clause allowing for psychological as well as physical trauma), the slipperiness of psychiatric evidence of emotional distress must be noted.

Second, the tying of sexual acts more tightly into notions of the self and identity enabled the broadening of accepted definitions of rape to include forced sexual encounters between spouses and acquaintances. As sex became linked increasingly to psychological events, shifting away from genitals and reproduction, the "wrongs" of date, acquaintance, and marital rape acquired much greater significance. These were attacks not simply on the body but on the very integrity of the self.

Third, the shift away from the social, and the increased psychologising of rape, also contributed to a change in the perceived appropriate response to abuse. Thus, we can trace a move away from demands for material reparation by the perpetrator towards mandated psychological healing of the victim. Trauma narratives insisted that victims took take responsibility for healing themselves. Politics and material inequalities were jettisoned; exchanged for speech-acts, or the redemptive potential of confessional speech. As feminist theorist Carine M. Mardorossian has convincingly argued in "Toward a New Feminist Theory of Rape" (2002), in contrast to second-wave feminism in which the victims showed that they were "more than the sum of their traumatic experiences, that they had the ability to act and organize even as they were dealing with the psychic effects of rape", in more recent years, victims are represented "as irremediably and unidirectionally shaped by the traumatic experience of rape and hence incapable of dealing with anything but their own inner turmoil" (743-75). The trauma narrative further implied that potential-victims act to prevent their own traumatisation. 


\section{FinAL WoRDS}

"Events" become traumatic according to the ascription of meaning. As the historian Mark Micale observed in relation to French psychiatry,

"trauma - as concept, theory, and experience - requires not just new 'events' but an altered sensibility, a change in the consciousness of change, which now becomes threatening, incomprehensible, and unmasterable" (Micael, 2001, 126).
The forensic texts and medico-legal languages explored in this article have been instrumental in attempting to "make sense" of sexual violence. Their efforts have been crucial to the process of constructing not only "the sex victim and sex offender" but sexuality itself. Rape narratives don't simply represent experience, but constitute it. Rendering the rape victim "insensible" and the shift from an emphasis on this insensible body to the psychological self have had dramatic effects on feminist praxis as well as legal conceptions of the female body.

\section{BIBLIOGRAPHY}

Abrahamsen, David (1960): The Psychology of Crime, New York, Columbia University Press.

Anon (1848): "Fright a Frequent Cause of Insanity, and Sometimes a Cure", American Journal of Insanity.

Bartley, Onesipherous W. (1815): A Treatise on Forensic Medicine or Medical Jurisprudence, Bristol, Barry and Son.

Bourke, Joanna (1996): Dismembering the Male: Men's Bodies, Britain, and the Great War, London, Reaktion Books.

Bourke, Joanna (2007), Rape: A History from the 1860s to the Present, London, Virago.

Brown, Laura S. (1995): "Not Outside the Range: One Feminist Perspective on Psychic Trauma", en Cathy Caruth (ed.), Trauma: Explorations in Memory, Baltimore, John Hopkins University Press.

Burgess, Ann Wolbert and Lynda Lytle Holmstrom (1974): "Rape Trauma Syndrome", American Journal of Psychiatry.

Cambridge Department on Criminal Science (1957): Sexual Offences. A Report of the Cambridge Department of Criminal Science, London, Macmillan.

Recibido: 1 de diciembre de 2008 Aceptado: 1 de mayo de 2009 of Legal Medicine, vol. 2, $2^{\text {nd }}$ edition, New York, E. B. Treat and Co.

Cowan, John (1869): The Science of a New Life, New York, Cowan and Co.

Dana, Charles Loomis (1898): Text-Book of Nervous Diseases and Psychiatry, $4^{\text {th }}$ edition, London: J. \& A. Churchill.

Duddle, M. (1991): "Emotional Sequelae of Sexual Assault", Journal of the Royal Society of Medicine, vol. 84.

Erichsen, John Eric (1875): On Concussion of the Spine, Nervous Shock, and Other Obscure Injuries of the Nervous System in Their Clinical and Medico-Legal Aspects, London, Longman, Green and Co.

Erichsen, John Eric (1866): On Railway and Other Injuries of the Nervous System, London, Walton and Maberly.

Galllichan, Walter P. (1928): Sexual Apathy and Coldness in Women, Boston, Stratford.

Janet, Pierre (1889): L'Automatisme psychologique, Paris, Evreux.

Jensen, Reynold A. (1947): "The Importance of the Emotional Factor in the Convulsive Disorders of Childhood", American Journal of Psychiatry.

Kardiner, Abram (1941): The Traumatic Neuroses of War, New York, Paul B. Hoeber.

McGuire, L. S. and Michael Stern (1976): "Survey Incidence of and Physicians' Attitudes Toward Sexual Assault", Public Health Reports, vol. 91. 
Mann, J. Dixon (1898): Forensic Medicine and Toxicology, $2^{\text {nd }}$ edition, London, Charles Griffith and Co.

Mardorossian, Carine M. (2002): "Toward a New Feminist Theory of Rape", Signs: Journal of Women in Culture and Society, vol. 27.

Melanson, Joan (1994): "Psychiatrist's Release of Confidential Information Causes Controversy in Halifax", $\mathrm{Ca}$ nadian Medical Association Journal, vol. 150.

Micael, Mark S. (2001): "Jean-Martin Charcot and les névroses traumatiques: From Medicine to Culture in French Trauma Theory of the Late Nineteenth Century", en Mark S. Micale y Paul Lerner (eds.), Traumatic Pasts: History, Psychiatry, and Trauma in the Modern Age, 1870-1930, Cambridge, Cambridge University Press.

Mills, Charles K. (1909): "Hysteria, What It Is and What It Is Not", American Journal of Psychiatry.
Napheys, George Henry (1884): The Transmission of Life. Counsels on the Nature and Hygiene of the Masculine Functions, Toronto, J. S. Robertson.

Northcote, Hugh (1906): Christianity and Sex Problems, Philadelphia, F. A. David Co.

Ogston, Francis (1878): Lectures in Medical Jurisprudence, London, J. \& A. Churchill.

Paris, John Ayrton y J. S. M. Fonblanque (1823): Medical Jurisprudence, London, Phillips, 1823.

Radzinowicz, L. (1957): Sexual Offences. A Report of the Cambridge Department of Criminal Science, London, Macmillan.

Root, Irving Wendell Ogden, y Wayne Scott (1974): "The Medical Examination of Alleged Rape", The Western Journal of Medicine, vol. 120.

Smith, Sydney (1925): Forensic Medicine. A Text-Book for Students and Practitioners, London, J. \& A. Churchill.

Stockham, Alice B. (1889): Tokology. A Book for Every Woman, Chicago, The Author.
Stone, Abraham and Lena Levine (195051): "Group Therapy in Sexual Maladjustment", American Journal of Psychiatry.

Storer, Horatio R. (1868): "The Law of Rape", The Quarterly Journal of Psychological Medicine and Medical Jurisprudent, vol. 2.

Sutherland, Sandra and Donald J. Scherl (1970): "Patterns of Response Among Victims of Rape", American Journal of Orthopsychiatry.

Tardieu, Ambroise (1878): Étude medicolégale sur les attentats aux mœurs, Paris, J. B. Bailliére et Fils.

Taylor, Alfred Swaine (1861): Medical Jurisprudence, $12^{\text {th }}$ edition, London, The Author.

Terry, Gladys C. (1929): "A Study in PsychoDynamic Patterns", American Journal of Psychiatry.

Zuspan, Frederick P. (1974): "Alleged Rape: An Invitational Symposium", The Journal of Reproductive Medicine, vol. 12. 